\title{
Actieonderzoek als leidraad om te transformeren? Een voorbeeld uit de praktijk
}

\author{
Chris Kuiper · Ellis ter Beek · Fieke Pannebakker · Leanthe van Harten
}

Published online: 5 November 2018

(C) Bohn Stafleu van Loghum is een imprint van Springer Media B.V., onderdeel van Springer Nature 2018

Het project Lerend Transformeren heeft als doel door middel van actieonderzoek professionals en hun organisaties te ondersteunen bij het ontwikkelen van een nieuwe werkstijl die past bij de transformatiedoelen. In deze bijdrage wordt dit project als voorbeeld belicht om te laten zien hoe actieonderzoek kan bijdragen aan de transformatie in de jeugdzorg.

\section{Inleiding}

Het is een turbulente tijd voor organisaties die betrokken zijn bij de jeugdzorg. $\mathrm{Na}$ de transitie zijn organisaties bezig te transformeren en met elkaar de zorg inhoudelijk te vernieuwen. Een van de opgaven voor professionals is het bewerkstelligen van een nieuwe 'werkstijl' gericht op de transformatiedoelen. De transformatiedoelen, vijf in totaal, kunnen gezien worden als de concretisering van het veranderde idee over jeugdhulp. In de Memorie van toelichting van de Jeugdwet zijn de vijf doelen beschreven (zie het kader) [1]. 'Preventief', 'normaliserend', 'op maat' en 'dichtbij huis', 'integraal' en 'met minder regeldruk' zijn steekwoorden die de beoogde transformatie weergeven.

\section{Opdracht voor professionals en jeugdhulporgani- saties}

Professionals en jeugdhulporganisaties behoren (al is het maar om continuïteit van werk te garanderen) het

\section{Dr. C. Kuiper · dr. E. ter Beek}

Horizon Jeugdzorg en Onderwijs, Rotterdam, Nederland

Dr. F. Pannebakker · L. van Harten

Child Health, TNO, Leiden, Nederland

Dr. C. Kuiper $(\square)$

Hogeschool Leiden, Leiden, Nederland

kuiper.c@hsleiden.nl gedachtegoed en de onderliggende waarden van de transformatie te omarmen. In de praktijk blijkt er echter behoefte te bestaan aan een nadere afbakening en invulling van dat begrip. De onduidelijkheid over het hoe roept de vraag op wanneer men het 'goed' doet. Daarbij staat buiten kijf dat het implementeren van een andere werkwijze niet (tijdelijk) ten koste mag gaan van de kwaliteit van zorg: 'Tijdens de verbouwing gaat de verkoop gewoon door.'

Om daadwerkelijk te transformeren wordt ook het nodige van het management en het bestuur van organisaties gevraagd. Van hen wordt immers verwacht dat zij hun professionals helpen met het invullen van de transformatiedoelen en de nieuwe werkstijl. Hoe je dat het beste kan doen, is voor veel organisaties onduidelijk.

\section{Actieonderzoek}

Het uitvoeren van actieonderzoek is volgens ons bij uitstek een geschikt middel om transformatie te ondersteunen. Dit type onderzoek heeft namelijk, naast een evaluatiefunctie, ook een actiefunctie [2]. Dat betekent dat het niet alleen gaat over het begrijpen, beschrijven of verklaren van de werkelijkheid, maar dat het doel is om anders te kunnen gaan handelen [3]. Actieonderzoek is met andere woorden gericht op het verkrijgen van kennis die aanwijzingen geeft over hoe te handelen.

\section{Actieonderzoek naar het ondersteuningsaanbod:} Lerend Transformeren

Doelstelling van het door ZonMw gefinancierde project Lerend Transformeren is professionals en hun organisaties ondersteunen bij het ontwikkelen van een nieuwe werkstijl gericht op de transformatie. Dit gebeurt door middel van actieonderzoek, gericht op de 
vraag: wat kan de organisatie doen om haar medewerkers naar deze nieuwe werkstijl te helpen? In het project voeren medewerkers van verschillende organisaties uit het gehele jeugddomein, vijftien in totaal, zelf actieonderzoek uit. Deelnemende organisaties zijn bijvoorbeeld actief in de jeugd- en opvoedhulp, jeugdgezondheidszorg, pleegzorg en jeugd-ggz.

\section{Een aanpak als voorbeeld: JouwZorg}

Een van de actieonderzoeken binnen Lerend Transformeren wordt uitgevoerd rondom JouwZorg, binnen Horizon Jeugdzorg en Onderwijs. JouwZorg richt zich op het vierde transformatiedoel: integrale hulp aan gezinnen volgens het uitgangspunt 'één gezin, één plan, één regisseur'. Het doel is om jongeren die door middel van een spoedprocedure in de JeugdzorgPlus worden geplaatst én hun ouders de regie terug te geven en de vormgeving van het vervolg na JeugdzorgPlus mee te laten bepalen. Vanaf het moment van plaatsing worden jongeren met hun systeem shared begeleid naar een zelfgekozen vorm van hulpverlening die bij hun krachten en ontwikkelbehoeften past. Hierdoor wordt de motivatie van de jongeren en opvoeders voor hulpverlening vergroot en wordt het eigen netwerk versterkt. Het resultaat van de gekozen behandeling of begeleiding verduurzaamt en er wordt minder een herhaald beroep gedaan op JeugdzorgPlus $[4,5]$.

\section{Het actieonderzoek}

Tijdens het actieonderzoek is JouwZorg gaandeweg in de praktijk ontwikkeld en onderzocht. Het motto van JouwZorg is: 'Nothing about us without us.' Dat is te zien in de inhoud van JouwZorg, maar betekent ook dat de jongeren, opvoeders en uitvoerders op gelijkwaardige wijze direct betrokken waren bij de (door)ontwikkeling van het project [6]. Er is ruim anderhalf jaar met JouwZorg geëxperimenteerd en tegelijkertijd is er een procesonderzoek uitgevoerd onder de deelnemende jongeren, hun JIM's (Jouw Ingebrachte Mentor) ${ }^{1}$ [7] en hun ouders.

Vragen die bij het actieonderzoek centraal stonden, zijn onder andere: hoe kun je samenwerking tussen de verschillende betrokken partijen (bijvoorbeeld gezin, netwerk, JeugdzorgPlus, jeugdbescherming, jeugdrechters, wijkteams, vervolgaanbieders) optimaliseren, met behoud van en respect voor ieders kennis en expertise? Wat helpt professionals daarbij en welke randvoorwaarden zijn er?

\footnotetext{
1 JIM staat voor Jouw Ingebrachte Mentor en is een familielid, vriend of bekende van de jongere. De keuze van een jongere voor een JIM wordt ondersteund door ouder(s), waarna de JIM optreedt als ambassadeur van de jongere. De JIM is de vertrouwenspersoon voor de jongere en zijn vertegenwoordiger richting ouder(s) en professionals.
}

Het actieonderzoek heeft geresulteerd in een handleiding waarin het werkproces van JouwZorg is beschreven en de werkzame elementen wetenschappelijk zijn onderbouwd [4]. Het actieonderzoek verschilt van veel vernieuwingsprojecten, omdat het onderzoek niet ophield na het uitproberen van de vernieuwing: er is ook onderzocht in hoeverre de verandering in de praktijk werkt en hoe het nog beter zou kunnen. Zo is er tegelijkertijd ook kennis en theorie ontwikkeld over de manier waarop de vernieuwing tot stand is gekomen.

\section{Geleerde lessen}

Ouders, jongeren en professionals bleken erg positief over de werkzame elementen van JouwZorg (met een JIM, shared en vanuit krachten werken om zelf een vervolg te kunnen kiezen). We hebben uit het actieonderzoek een aantal waardevolle lessen getrokken, die als volgt zijn samen te vatten:

1. De effectiviteit van een innovatie als JouwZorg wordt bepaald door een goed beschreven methodiek, maar vooral door de attitudes en vaardigheden van de betrokken partijen die de methodiek uitvoeren. In het geval van JouwZorg betekent dit dat bij aanvang minimaal een training in shared decision making, JIM en Krachtwerk (onderdeel krachteninventarisatie) aangeboden moet worden om de medewerkers hier concrete kennis en vaardigheden over aan te bieden.

2. Aan de kwaliteit van werken moet blijvend aandacht worden gegeven. Het kennen, begrijpen en zelfs gevoelsmatig ondersteunen van methoden is onvoldoende om deze doorleefd aan te kunnen bieden aan een zeer diverse en complexe doelgroep in een gesloten context. Bij JouwZorg wordt daarom nu structureel intervisie georganiseerd om continu te blijven ontwikkelen.

3. Het betrekken, horen en meebeslissen van alle partijen is binnen JouwZorg cruciaal gebleken. Het kan echter veel tijd kosten om alle dagelijkse handelingen op die manier aan te pakken. Daarom is het belangrijk om zo snel mogelijk te signaleren wanneer verwachtingen uit elkaar (dreigen te) lopen en dit bespreekbaar te maken. Om het behapbaar te houden, is er gaandeweg voor gekozen om de groep professionals die op verschillende momenten bij besluitvorming aanwezig is te beperken. Ook met het oog op de balans tussen gezin en professionals bleek dat wenselijk, want wanneer er te veel professionals aan tafel zitten, zal het gezin minder regie voelen en nemen.

4. Ten slotte is draagulak in de organisatie nodig. Dit lijkt een open deur, maar blijkt in de praktijk de maker of breker van een innovatie. Pas als de principes van JouwZorg door het aansturend kader worden onderschreven en gedwongen behandeling ook door hen als minder wenselijk wordt gezien, komt 


\section{De vijf transformatiedoelen zijn:}

1. Preventie en uitgaan van eigen verantwoordelijkheid en eigen mogelijkheden van jongeren en hun ouders, met inzet van hun sociale netwerk. Lees ook meer in het dossier Van jeugd naar volwassenheid.

2. Demedicaliseren, ontzorgen en normaliseren door onder meer het opvoedkundige klimaat te versterken in gezinnen, wijken en scholen, en in voorzieningen als kinderopvang en peuterspeelzalen.

3. Eerder de juiste hulp op maat bieden om dure gespecialiseerde hulp te verminderen.

4. Integrale hulp aan gezinnen bieden volgens het uitgangspunt 'één gezin, één plan, één regisseur'. Door ontschotting van budgetten ontstaan meer mogelijkheden voor betere samenwerking en innovaties in hulp aan jongeren. Lees ook meer in het dossier Van jeugd naar volwassenheid.

5. Meer ruimte voor professionals door vermindering van regeldruk.

er ruimte voor een innovatie als JouwZorg. Een gedragswetenschapper en afdelingshoofd dragen het gedachtegoed van JouwZorg uit in het team, ze inspireren en scheppen de voorwaarden (onder andere consultatie, intervisie, aansturing vanuit de bedoeling, monitoring van het teamproces en de inhoudelijke trajecten). Dit is broodnodig, gezien de complexe realiteit waarin onze medewerkers met innoveren bezig zijn.

\section{Beschouwing}

Over transformaties in de (residentiële) jeugdhulp is het laatste woord nog niet gezegd. We constateren dat het gaandeweg in de praktijk ontwikkelen van een aanpak, samen met alle betrokken partijen, beloftevol is. Het werkt onzes inziens alleen als de organisatie, het management, de professionals, ouders en jongeren allen de andere zienswijze ondersteunen en omarmen. Een systeemverandering breng je met elkaar tot stand.

Transformeren is duidelijk geen one size fits all-proces: het gebeurt altijd in context. Wij hebben de inzet van actieonderzoek als een zeer passende werkvorm ervaren. We sluiten ons graag aan bij de uitspraak van Kurt Lewin (een van de grondleggers van actieonderzoek): 'Als je iets echt wilt begrijpen, probeer het dan te veranderen' (If you truly want to understand something, try to change it.) [8, 9]. Ons inzicht in de complexiteit van de transformatie is toegenomen, evenals dat in de mogelijkheden en onmogelijkheden van alle betrokkenen.

\section{Literatuur}

1. Tweede Kamer der Staten Generaal. Memorie van toelichting Jeugdwet; kamerstuk, 1 juli 2013. https://www. rijksoverheid.nl/documenten/kamerstukken/2013/07/ 01/memorie-van-toelichting-bij-de-jeugdwet. Geraadpleegd op 26 september 2016.

2. Eden C, Huxham C. Action research for management research. BrJ Management. 1996;7:75-86.

3. Migchelbrink F. De kern van participatief actieonderzoek. 2edruk. Amsterdam: SWP; 2018.

4. Beek E ter, Baarle E van, MunninghoffX et al. Handleiding JouwZorg Prototype 3 experimentele fase. Rotterdam: iHUB \&JSO; 2018.

5. Wolf J. Krachtwerk: methodisch werken aan participatie en zelfregie. Bussum: Uitgeverij Coutinho;2016.

6. Kuiper C. Schuldig landschap? De afwezigheid van de getuigenis van het veld. Lectorale rede. Amsterdam: uitgever SWP; 2017.

7. Dam L van, Verhulst S. De JIM-aanpak. Het alternatief voor uithuisplaatsing van jongeren. Boom uitgevers: Amsterdam;2016.

8. Lewin K. Action research and minority problems. In: Lewin GW, redactie. Resolving social conflicts. New York: Harper \&Row; 1948. pag. 201-16.

9. Bargal D. Personal and intellectual influences leading to Lewin's paradigm of action research. Towards the 60th anniversary of Lewin's 'Action research and minority problems'. Action Res 2016;4(4):367-88. 